Canadian Journal of Higher Education Revue canadienne d'enseignement supérieur

Volume 47, No. 2, 2017, pages 135 - 155

\title{
Experiences of Students Enrolled in Integrated Collaborative College/ University Programs
}

Janet Landeen, Nancy Matthew-Maich, Leslie Marshall, Lisa-Anne Hagerman, Lindsay Bolan, Maurine Parzen, Maria Pavkovic, Christine Riehl, Joshua Carvalho, Natasha Bilau, Zetian Zhang, Sheri Oliver, Jacob Cottreau, and Bhavin Shukla

\begin{abstract}
Little is known about the student experience in collaborative college/university programs, where students are enrolled in two institutions simultaneously in integrated curriculum designs. This interpretive, descriptive, qualitative study explored these students' perspectives. Sixty-eight participants enrolled in one of four collaborative programs from three different faculties engaged in student researcher-led focus groups. Results revealed that while all participants valued their respective academic programs, their day-to-day life experiences presented a different story. Some students had perceptions of belonging and thrived in a dual world. Others had perceptions of ambiguous belonging, which contributed to them perceiving themselves through a perpetual lens of being less than university-only students. Issues of how students are invited to engage in the university and college cultures, perceptions of power and control, and daily reminders of being different all contributed to positive or ambiguous student identities. The results raise preliminary questions for universities and colleges regarding how to enhance the student experience in these collaborative programs.
\end{abstract}




\section{Résumé}

On en connaît peu sur l'expérience des étudiants dans les programmes collégiaux/universitaires collaboratifs, où les étudiants sont inscrits simultanément dans deux institutions dans un modèle de curriculum intégrés. Cette étude qualitative descriptive interprétative explore les perspectives de ces étudiants. Soixante-huit participants se sont inscrits dans l'un des quatre programmes collaboratifs de trois facultés différentes impliqués dans des groupes de discussion de chercheurs dirigés par les étudiants. Les résultats ont révélé que bien que tous les participants apprécient leurs programmes académiques respectifs, leurs expériences quotidiennes ont présenté une histoire différente. Certains étudiants ont eu la perception d'appartenance menant à prospérer dans un monde dual. D'autres ont eu la perception d'une appartenance ambiguë contribuant à percevoir à travers une lentille d'infériorité perpétuelle. Des problèmes sur la façon que les étudiants sont invités à participer dans les cultures universitaires et collégiales, les perceptions de pouvoir et de contrôle, et un rappel quotidien d'être différent ont tous contribué à l'identité positive ou ambiguë des étudiants. Les résultats soulèvent des questions préliminaires pour les universités et collèges sur la façon d'améliorer l'expérience des étudiants.

\section{Introduction}

Over the past 15 years, collaborative educational programs between colleges and universities in Ontario have grown exponentially. Given the complexity and uniqueness of such programs, very little is known about the students' day-to-day experience of being enrolled in college and university simultaneously. This study was conducted to gain an understanding of the perceptions of students enrolled in healthcare and non-healthcare collaborative programs, in order to optimize the student experience.

Collaborative degree-based programs are characterized by formal agreements between colleges and universities that delineate the program model and governance structures (amongst other considerations) to facilitate students' learning (Kirby, 2008). Program designs range from sequential learning, where students take courses from one institution at a time, to fully integrated models, where students are enrolled in two institutions simultaneously. The growth of these collaborative educational programs in Ontario has historical connections to the 2005 change to baccalaureate degree requirements for registered nursing practice (Pringle, Green, \& Johnson, 2004) and the 2006 Ministry of Training Colleges and Universities (MTCU) funding changes that provided "grants to increase the number, type, and range of collaborative arrangements" (Armstrong, 2008, p. 4). While collaborative nursing programs are now the most common form of nursing degree education in Canada (Kirby, 2008), other collaborations are also increasing in number. According to the Ontario Universities Application Centre (2014), as of 2015, there were 96 different collaborative programs open for admission in Ontario. To date, the published analyses of these programs have mainly focused on students moving sequentially between separate college and university programs (Boggs \& Trick, 2009; Decock, McCloy, Liu, \& $\mathrm{Hu}, 2011$; Kerr, McCloy, \& Liu, 2010). There is limited literature focusing on educational 
programs that are designed as fully integrated models of collaboration. While there have been some indications of what makes for a successful partnership (Kirby 2007; Zawaduk et al., 2014; Zorzi et al., 2007), the literature has examined this topic from institutional and faculty perspectives. There has been very limited study of student perspectives.

One online survey of 1,332 nursing students and graduates was completed as part of evaluating collaborative nursing programs in Ontario (Zorzi et al., 2007). In that study, student perspectives were reported together with those of faculty and staff and revealed some strengths (smaller, friendlier atmosphere in the colleges and more resources in the universities) and some challenges (differences in expectations between colleges and universities, difficulties in transitions between sites, and differences navigating the administrative structures of both). In a mixed quantitative-qualitative study of one collaborative nursing program that utilized a sequential delivery model, Cameron (2005) found that students experienced transition stress as they moved from college to university. Students reported stress related to geographical relocation, academic shock, professional transformation related to differing perceptions of nursing, and a constrained social life. This study called for a more seamless curriculum between the two institutions.

There is a body of literature that explores the relationship of the student experience, specifically student engagement, with various measures of student success across different ages, cultures, and settings (Audas \& Willms, 2001; Elffers, Oort, \& Karsten, 2012; Hausmann, Schofield, \& Woods, 2007). Studies show that students who identify with school are more likely to participate and be emotionally engaged (Fredericks, Blumenfeld, \& Paris, 2004), both of which are components of Finn's $(1989,1993)$ concept of school engagement. While these perspectives originated from studies with primary and secondary school children, the idea of identity and participation being part of student engagement has been extended to the postsecondary setting (Elffers et al., 2012). Students who are enrolled in integrative collaborative programs need to engage both emotionally and behaviourally with two different institutions simultaneously. Limited literature has been found to explore the issue of student engagement and identity related to the school experience.

Given the increase in the number of collaborative programs, the gap in the literature on the experience of students enrolled in integrated collaborative programs, and the importance of emotional and behavioural engagement with school, it is timely to explore student experiences of being part of an integrated, collaborative college/university program, and what it means to be a student with a "dual identity."

\section{The Setting}

The study was conducted in South Central Ontario, where one university and two community colleges partnered to offer four integrated collaborative programs across three faculties. While there are some similarities within the structures of these programs, variations in practices and policies have emerged that may impact the student experience. Three of the four collaborative programs of "Wayland" University (pseudonyms used) are with "Eastman" College: a Bachelor of Science in Nursing, a Bachelor of Medical Radiation Sciences, and a Bachelor of Technology. One is with "Westover" College: a Bachelor of Science in Nursing. All programs are governed through distinct memorandums of understanding. Please See Table 1 for a summary of the collaborative programs. 
Table 1. Summary of Collaborative Programs

\begin{tabular}{|c|c|c|c|c|}
\hline Name of Program & Location & $\begin{array}{c}\text { Year } \\
\text { Established }\end{array}$ & $\begin{array}{l}\text { Number of } \\
\text { Students } \\
\text { Enrolled in } \\
\text { Sept. } 2014\end{array}$ & Curricular Features \\
\hline $\begin{array}{l}\text { Wayland U - } \\
\text { Eastman C BScN } \\
\text { (East-Way) }\end{array}$ & $\begin{array}{l}\text { AA city, on campus, } \\
\text { mostly in shared } \\
\text { Wayland/Eastman } \\
\text { building. }\end{array}$ & 1996 & 666 & \multirow{2}{*}{$\begin{array}{l}\text { Integrated four-year pro- } \\
\text { gram, identical curriculum } \\
\text { to BScN program offered to } \\
\text { Wayland U site students. } \\
\text { - Graduates receive BScN } \\
\text { degree. }\end{array}$} \\
\hline $\begin{array}{l}\text { Wayland U - } \\
\text { Westover C BScN } \\
\text { (West-Way) }\end{array}$ & $\begin{array}{l}\text { BB city, } 45 \text {-minute } \\
\text { drive. }\end{array}$ & 1996 & 610 & \\
\hline $\begin{array}{l}\text { Wayland U - } \\
\text { Eastman C } \\
\text { Medical Radiation } \\
\text { Sciences } \\
\text { (MedRadSci) }\end{array}$ & $\begin{array}{l}\text { AA city, on campus, } \\
\text { in shared Wayland/ } \\
\text { Eastman building. }\end{array}$ & 2005 & 487 & $\begin{array}{l}\text { Integrated four-year pro- } \\
\text { gram, } 10 \text { terms in length. } \\
\text { Streamed into one of three } \\
\text { specializations at end of } \\
\text { year one. Graduates receive } \\
\text { MRSc degree from Way- } \\
\text { land U and OCAD from } \\
\text { Eastman C. }\end{array}$ \\
\hline $\begin{array}{l}\text { Wayland U - } \\
\text { Eastman C Bach- } \\
\text { elor of Technology } \\
\text { (BTech) }\end{array}$ & $\begin{array}{l}\text { AA city, on campus; } \\
\text { specialized building } \\
10 \text { minutes from main } \\
\text { campus; and East- } \\
\text { man campus, } 30-40 \\
\text { minutes by public } \\
\text { transportation. }\end{array}$ & 2007 & 814 & $\begin{array}{l}\text { Four-and-a-half-year } \\
\text { collaborative program. } \\
\text { Graduates receive Wayland } \\
\text { U BTech degree, Eastman } \\
\text { College Advanced Diplo- } \\
\text { ma, and Eastman C Busi- } \\
\text { ness Certificate, 12-month } \\
\text { co-op experience. }\end{array}$ \\
\hline
\end{tabular}

Note: Wayland University, Eastman College, and Westover College are pseudonyms.

In 1996, Wayland University signed articles of agreement with Eastman and Westover Colleges to establish a collaborative Bachelor of Science in Nursing (BScN) degree. In addition, since 1946 Wayland U has offered a standalone BScN program, which is situated within the Faculty of Health Sciences. The curriculum is the same for all students, regardless of site. Given the geographical proximity of Wayland U and Eastman C, students in the collaborative Wayland U-Eastman C (East-Way) program are periodically intermingled in the same classes as Wayland U students. Wayland U students are taught exclusively by Wayland U faculty, while East-Way students are taught by both Eastman C and Wayland $\mathrm{U}$ faculty. The Wayland U-Westover C (West-Way) students remain at that campus for the duration of their program, with Wayland U faculty travelling to Westover $\mathrm{C}$ to teach a portion of the classes. Students from all sites and streams engaged in a small-group, problem-based learning format (12-20 students per group) for most nursing theory courses. Students from the Wayland U site apply for admission through the 
Ontario University Application Centre, while students from both of the college sites apply through the Ontario College Application Service.

The Medical Radiation Sciences (MedRadSci) program was established in 2005 as a collaboration between Wayland University and Eastman College in the Faculty of Science. The impetus for the program was the 1995 initiative of the Canadian Association of Medical Radiation Technologists to establish degree entry-to-practice requirements for medical radiation technologists. This program is unique, as it offers specialized knowledge in professional practice in three specializations within medical radiation sciences-radiological technology, ultrasonography, and radiation therapy - with a strong foundation in the basic sciences. Students apply to the MedRadSci program through the Ontario University Application Centre and are taught by faculty from both Wayland $U$ and Eastman $C$ in one seamless program. Students are streamed into one of the three specializations at the end of their first year.

The Bachelor of Technology (BTech) program, housed within the Faculty of Engineering at Wayland University, was established in 2007. The program offers a fresh approach to education in engineering, and students specialize in one of three streams: automotive and vehicle technology, biotechnology, or process automation technology. Students engage in "learning in $3 \mathrm{D}$ " which means that theory, practice, and experience are incorporated in the program through lectures, labs, and work experience. Students utilize the laboratory facilities at both Wayland $\mathrm{U}$ and Eastman $\mathrm{C}$ and are taught by instructors from both institutions. The amount of time a student spends on the Eastman $\mathrm{C}$ campus varies depending on what level of the program the individual is in as well as the student's stream of specialization. Students may have between one and six labs at Eastman $\mathrm{C}$ per semester. They participate in lectures with approximately 50-60 other students, as well as smaller classes in laboratory settings.

\section{Methodology}

The qualitative research paradigm addresses questions related to the meanings and interpretations of the human experience (Denzin \& Lincoln, 2011), particularly in an area where little is previously known. This study employed an interpretive, descriptive, qualitative research design to explore the student experience (Thorne, 2008). This methodology was appropriate since the goal of the research was to apply the findings to inform practice rather than to generate theory or explore the essence of a phenomenon (Thorne, 2008). This design addressed "the challenge of retaining the coherence and integrity of a theoretically driven approach to knowledge development while supporting defensible design variations according to the specific features of context, situation, and intent” (p. 27). Thus, the researcher was called upon to systematically address and defend each methodological decision. Based on constructivist philosophy, the researcher acknowledges his/her own perspectives and values and their potential impact on uncovering the meanings of participants' experiences or stories. Interpretive description moves beyond descriptive qualitative research in examining complex issues. Within interpretive description, the researcher does not identify a theoretical understanding prior to conducting the research (Hunt, 2009).

Paid student researchers (SRs) from the four respective programs (East-Way BScN, West-Way BScN, MedRadSci, and BTech) were recruited as co-investigators. They were mentored through all phases of the development and execution of this project. Focus groups were used for data collection, as they provide a valuable window to real conversations in a near-naturalistic setting (Kevern \& Webb, 2001; Warr, 2005; Wilkinson, 1998), 
which can reveal social processes and cultural norms (Duggleby, 2005; Freeman, 2006; Hollander, 2004). Discussion of sensitive topics is often facilitated in focus groups because participants are with others who share similar issues (Kevern \& Webb, 2001). More so than individual interviews, focus groups empower participants to initiate issues of concern to them, which frequently leads to the collection of important data that may have been missed otherwise (Wilkinson, Rees, \& Knight, 2007).

SRs contributed their unique perspectives when we finalized the focus group questions. These questions were also informed by the literature on student engagement, previous program-specific student in-course and exit surveys, and town hall meetings (see Table 2).

Table 2. Semi-Structured Focus Group Questions

1. What are your overall impressions of your particular program [name programs of participants: East-Way nursing, BTech, etc.]?

2. What college and/or university activities outside of classes are you involved in?

3. Which institution do you feel most closely connected to and why?

4. As a student in [name of program] how do you feel you are perceived by others?

5. What have been your experiences with respect to the strengths and challenges of being in [name the program]?

6. If you were to explain your joint college/university program to a stranger, what would you say?

7. What are your perceptions about your access to resources?

8. Is there anything else that they would like to share but have not yet had the opportunity to do so?

9. Highlight key points of discussion (recorder/observer may be in the best position to do this). Ask participants: Is the summary reflective of your experiences and what you shared today in the focus group? Any revisions, additions, clarifications?

The SRs assisted in the recruitment of participants, and two SRs from different programs, wherever feasible, facilitated the audiotaped focus groups. Following the final student focus group but prior to data analysis, all SRs were participants in a focus group facilitated by the Principal Investigator (JL) to explore their perceptions of being a student in a collaborative program. This final step was completed to support researchers' efforts to avoid inadvertently inserting their own perceptions during the data analysis phase (Thorne, 2008). A full discussion of the SR role in this research will be forthcoming in a future publication.

Verbatim transcriptions were made, and data were anonymized prior to analysis. Data analysis was conducted using Thorne's (2008) steps for analysis: confirming your bases, expanding on associations, testing relationships, capitalizing on outliers, and engaging the critic. In addition, Morse and Field's (1995) four intellectual processes of comprehending, synthesizing, theorizing, and re-contextualizing were used to uncover themes from the data. Each researcher, including the SRs, independently coded selected transcripts, with three faculty researchers coding all transcripts. Themes and exemplars were identified through consensus meetings of all researchers. A secondary literature search was conducted based on the emerging themes to better understand the study's findings. Approval was obtained from the research ethics review boards of all three institutions prior to data collection. 


\section{Participants}

All students above the first year in the designated programs were eligible for inclusion in this study. First-year students were excluded to ensure that issues common to transition into higher education (Garcia Bedolla, 2010; Smith \& Zhang, 2009) were not conflated with issues arising from being in collaborative educational programs. Ten focus groups were held with a total of 68 participants (25 East-Way BScN, 11 West-Way BScN, nine MedRadSci, and 23 BTech). Forty-nine percent of the participants were male, and the average age of the participants was 22. Participants were in their second ( $n=14)$, third $(n=28)$, or fourth $(n=26)$ year of their respective programs. The majority of students entered the program directly from high school (66\%), with $26 \%$ having previous college education and only $7 \%$ having previously attended university. Only two students (3\%) lived in on-campus housing, 40\% lived in off-campus student housing, and $57 \%$ lived with their parents or independently as mature students. Additional demographic details were not collected, as it would have been nearly impossible to determine which student, with what demographic characteristics, made any given remark within the focus group setting.

\section{Results}

Analysis of the focus group transcripts revealed rich data with multiple overlapping exemplars, which coalesced into themes. Results from this study revealed that there are dual realities of having a "dual identity," that is, of co-existing in two institutions simultaneously. Perceptions of learning and perceptions of identity may be closely aligned or highly disparate. While students all valued their respective academic programs, the dayto-day life experiences of being a student simultaneously in two institutions presented a different story, as depicted in Figure 1.

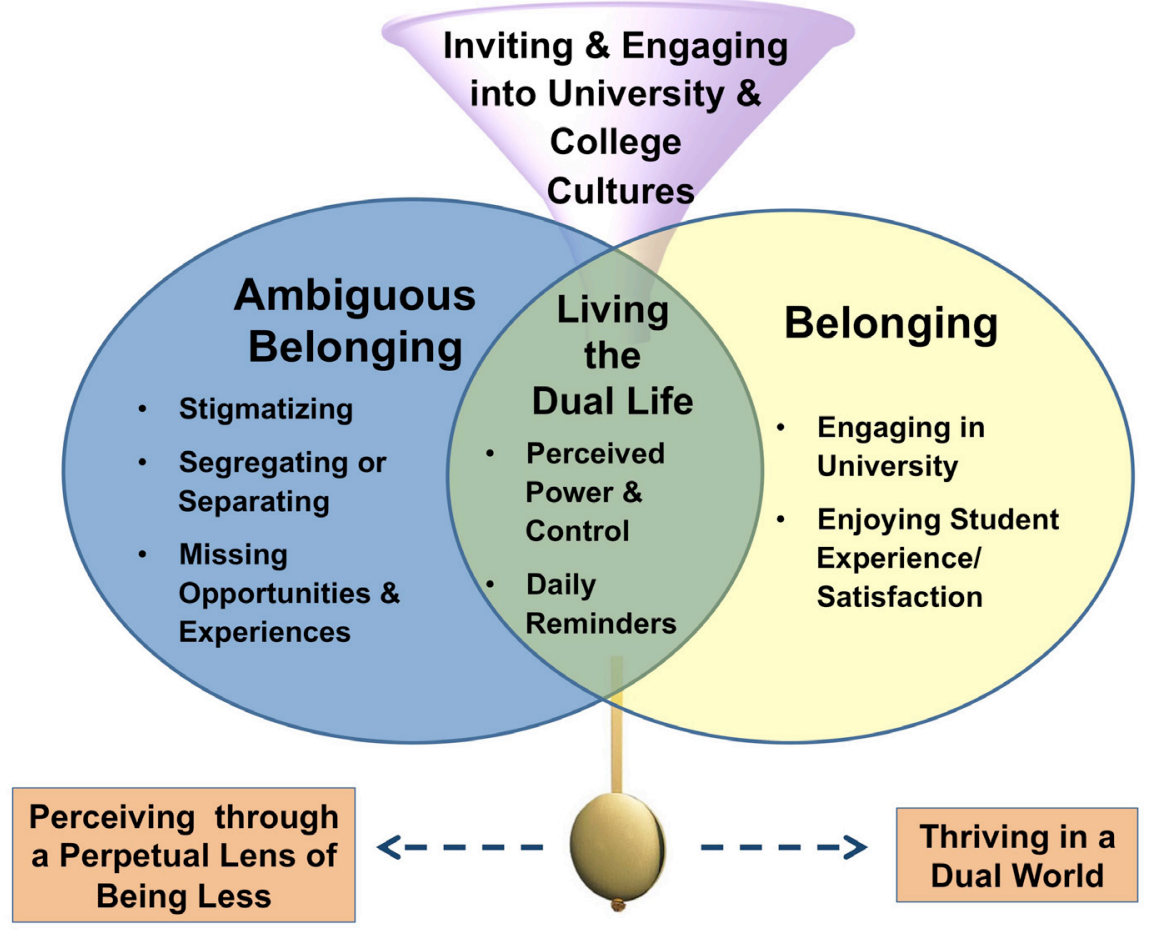

Figure 1. The Collaborative Student Experience 
There were variations across programs, with some students being more likely to have perceptions of belonging, characterized by engaging in the university setting and enjoying the student experience, leading to thriving in a dual world. Students in the other programs were more likely to have perceptions of ambiguous belonging, in which they described stigmatizing and segregating or separating experiences and perceived missed opportunities. For these students, this contributed to perceiving through a perpetual lens of being less, whereby they misinterpreted existing institutional policies and processes. Potential influences on students' perceptions became apparent when we analyzed the differences in experiences, policies, and practices across programs. Issues of how students are invited to engage in the university and college cultures, perceptions of power and control, and daily reminders of being different all contributed to positive or ambiguous student identities.

\section{Perceptions of Learning}

Participants across all programs spoke with pride about their educational programs and the fact that they were earning a university degree. They reported feeling a sense of community and support within their classes. Participants from the BScN, BTech, and MedRadSci programs noted smaller class sizes and a greater focus on experiential learning as positive features of being in collaborative programs. In addition, MedRadSci and BTech participants believed that they were more "work ready" than their university-only educated peers. As one BTech participant stated, "[T]he combination of the practical experiences from the college side and the theoretical experiences from the university side ... at the end I would have both an advanced diploma of technology and a bachelor of technology."

Study results revealed that participants from the MedRadSci and BTech programs also perceived that graduate education was an option after graduation, which would not necessarily be possible with college-only programs. Nursing student participants did not raise this comparator, as they stated that the curriculum was the same whether attending a collaborative or a university-only site. BScN participants from the Eastman C site valued the greater heterogeneity in the student body: "I kind of like that about our program though, because you get more diversity, instead of just having a group of Wayland U students coming from high school" (East-Way BScN participant).

\section{Perceptions of Identity}

Participants varied in how they perceived themselves as college and university students. This shifted between a unified sense of belonging simultaneously at two institutions and in one unified program, and a fragmented or ambiguous sense of belonging, along with a feeling of not being entirely comfortable anywhere. While all participants shared both integrative and disorienting experiences, there was noticeable variation across programs. When asked how they would describe their program to a stranger, many students discussed the rigours of university-level work compared with the practicality of the college. They also discussed the challenges of describing a collaborative program to the general public: "It's very hard to, like, describe what we actually are doing here; people just have a very hard time understanding that it is a university program" (WestWay BScN participant). 
Belonging. Some student participants described a strong sense of belonging, perceiving their program and experience as indicative of a unified community. They were able to identify the contributions made by both the college and the university, and they moved seamlessly across the institutions. The students perceived themselves as no different from other students at either the university or the college. Interestingly, MedRadSci participants, who had no direct comparator student group at the university or the college, were most likely to endorse belonging. They spoke of getting the best of both institutions:

if you know what you want to do it's a good program to get into. You graduate with a job, you have two separate degrees and [it] points you to a specific path that you will be able to get a job in easily.... I think all that is really well done because we have access to both Wayland U and Eastman C libraries . . . and other resources. (MedRadSci participant)

West-Way nursing participants described identifying themselves as Wayland U students for their résumés or to explain the rigour of their program, but felt closer to Westover C on a day-to-day and emotional level:

I tend to just tell people that I go to Wayland University instead of just telling them I go to Westover $\mathrm{C}$ and Wayland $\mathrm{U}$ because it's much easier to explain. Because people don't understand, because even though I talk about Wayland U but I'm studying at Westover C, they go, "Oh, do you get a diploma after this?” (West-Way $\mathrm{BScN}$ participant)

However, they also felt a strong connection to Westover C:

And I would say [I am] probably more connected with Westover $\mathrm{C}$ because in 4 years ... I think I have been to Wayland U maybe two or three times. And everything else, my extra-curricular and my [course] work revolves around this campus. (West-Way BScN participant)

Engaging in university. A sense of belonging was characterized by early engagement with student life at the university. Participants discussed living in Wayland U student housing and joining Wayland U clubs and activities. They described feeling welcomed by the wider university campus and proud to explain their unique program. This was most apparent with MedRadSci participants, who then went on to explain that they could access Eastman $\mathrm{C}$ facilities when needed or desired. When asked which institution they felt more connected to, one participant stated: "Wayland U. We stayed here first year, we stayed on this campus, and all of our classes were on this campus, so it feels like you are just closer to the Wayland U community" (MedRadSci participant).

Enjoying student experiences/satisfaction. For some students, the sense of belonging was reflected in their strong satisfaction with their experience and their program:

I love it, I love the program, I love ... being in small groups, and working on case scenarios, and being in a clinical group that's small. And I feel like I have been able to grow in my confidence and my leadership. (West-Way BScN -participant) 
Some student participants had only positive comments to make about their choice of enrolling in a joint college/university program:

I feel like because [my courses] are collaborative, I feel like I am a Wayland U student. I also have the experience of what college feels like, so I don't feel like, "I wish I went to college instead." I am going to both, so I can enjoy both and take the positive from both at the same time. (BTech participant)

Thriving in a dual world. Participants with a strong sense of belonging moved through their programs with relatively few challenges. They utilized resources from both settings and navigated paths through their educational experiences with what they perceived as the same strengths and challenges as any other university or college student. In contrast, a much larger percentage of participants described an alternate reality.

Ambiguous belonging. Many participants described a fragmented, disjointed, or ambiguous sense of belonging. They did not feel that they belonged to either institution; rather, they were living in a "no-man's land," with the program itself providing some sense of identity. "I feel like there wasn't that connection, like, to join anything [at Wayland U]. It was always like you didn't know if you were Eastman C or if you were Wayland U” (East-Way BScN participant). Participants described distressing experiences that characterized this sense of separateness.

Stigmatizing. Participants described multiple examples of experiencing stigma from faculty, from staff, and most commonly from other university students. One EastWay nursing student described meeting her new off-campus roommate:

So I remember the first day she moved in, I was asking her about how there's EastWay nursing, and she's like, "Yeah, it's kind of bull . . . , like, there's all these Eastman $\mathrm{C}$ students and they end up with the same degree but they're, like, not as smart as us." ... And I was like, "Yeah, I'm East-Way," and she's like, "Oh, sorry." (East-Way BScN participant)

Other participants described the pejorative labels they were given by other university students from within their same faculties: "We are perceived as the fake engineers, the 'Pretendengineers"” or "[we are called] 'BTech/Rejects,' so I'm a 'ReTech"” (two BTech participants).

Participants described hearing university faculty state that students in collaborative college/university programs have more challenges academically than university-only students. The perceived that lower entrance admission averages for students enrolling in collaborative programs were mentioned in classes, providing fuel for such student comments as: "One time I was explaining to someone and he's, like, 'Oh, so you just weren't smart enough to get into the Wayland U program"' (East-Way BScN participant). There was general agreement amongst all focus groups that these types of experiences were common, with the exception of the MedRadSci students.

Segregating or separating. Student participants described situations where they chose to remain separate from either the university or the college at large or perceived that they were segregated by others. "Since you have all your classes together, you have all your own ideas all in the same class, [so] it's easy to say, 'Let's go study together" (BTech participant). Because the programs are unique, a natural separation occurs. 
There is no one like us in our school, so we are kind of separate. But we do take advantage of that. The downside is that there is no one else, so we don't have anybody else to really look up to, so we are basically separate from the rest of Wayland U. But we don't really belong at Eastman C either, so we are kind of just isolated; that's basically the only downfall. (MedRadSci participant)

On the other hand, BTech participants shared that they wanted to be part of the community, that this was "half the fun of being at university . . . but I wouldn't say [we are] excluded, but you could tell we're not number one on the list."

Missing opportunities and experiences. Participants described situations where they perceived that they did not have the same opportunities or experiences as other students. This was particularly true for the East-Way nursing students, who described their experiences of not having access to Wayland $U$ student residences and of not being eligible to book classroom space in the main library. Other participants described distance as impacting their ability to access resources:

We get missed opportunities because we are not at the main campus. Wayland $\mathrm{U}$ is obviously larger, so they have more opportunities for extra continuing education courses or guest speakers, that kind of thing. We just don't get the opportunity to participate unless we are willing to drive to [name of city] and participate that way. (West-Way BScN participant)

Perceiving through a perpetual lens of being less. The experiences of ambiguous belonging led to perceptions of being less than university-only students. Participants described perceptions of having fewer opportunities, even when the reality from the institutional perspective was that the opportunities were identical: "Wayland U [BScN students] get first choice, first dibs for clinical placements, and then East-Way. We just get the short end of the stick" (East-Way BScN participant). The implications of lowered selfperceptions may carry on after graduation. As one BScN participant eloquently stated:

At Wayland U site specifically, they are told that they [have] higher expectation[s]; they are better than the other site. So it has more implications on even other occupations, even when they're in the workforce. Because they turn into the RN role, where they are better than everyone else. (East-Way BScN participant)

Overall the sense of belonging was dynamic, with participants alternating in describing various experiences. They offered up potential contributing factors to their identities, including issues related to institutional policies and practices, and the impact of day-today experiences. A look at policies across programs supported the experiences described by the participants.

Inviting and engaging in university and college cultures. Participants contrasted their experiences from the application process through to ongoing university and college policies. All participants discussed the need for greater clarity in anticipatory communication. For example, East-Way BScN participants described being offered student residence by Eastman $\mathrm{C}$ admissions officers. They did not realize until arriving for the beginning of classes that the Eastman $\mathrm{C}$ residences are located on the main Eastman $\mathrm{C}$ campus, a 30- to 40-minute bus ride away, not on the Wayland U campus, where they take classes. Orien- 
tation sessions were alternately integrated and segregated: "I think from the beginning it needs to start out with us together instead of the Wayland $U$ orientation and the Eastman C orientation" (East-Way BScN participant). Conversely, West-Way participants described the orientation to Wayland $U$ as irrelevant when they were entering the program. They discussed learning the layout of the Wayland U campus, which they rarely visited, but being lost without a similar orientation to Westover C. Many details were provided by East-Way $\mathrm{BScN}$ participants, in particular about having confusing experiences during their first week of school, feeling excluded from orientation activities because not all events were covered by their student fees, or needing to have two different student cards.

Students also discussed the disparity of information across the institutions. They suggested that "both institutions [should let] the students know what resources are available. ... We know nothing about Eastman $\mathrm{C}$ and . . . a good chunk about Wayland U. It would be good to have the information from both sides" (BTech participant).

Living the dual life. Day-to-day experiences influenced the degree to which students identified with one or both institutions simultaneously. A number of participants across programs said proximity to resources and campuses greatly impacted their sense of belonging. For example, MedRadSci students took their first-year courses integrated with other students on the Wayland U campus and had other classes in the shared EastWay building, located on the Wayland U campus. They rarely travelled to the main Eastman $\mathrm{C}$ campus and tended to view the shared building as part of belonging at Wayland $\mathrm{U}$; thus, they identified more strongly with Wayland U. Conversely, all of the West-Way nursing students' classes were located at Westover $\mathrm{C}$, and they rarely, if ever, travelled to the Wayland U campus. While they valued the convenience of having classes offered close to home, they also discussed feeling alienated and forgotten by the university.

Two participants in one West-Way BScN focus group were at polar ends of the spectrum regarding feeling connected to Wayland U. In sharing their perspectives, one participant indicated that she was highly involved with the collaborative nursing student society and thus felt a sense of belonging with Wayland U. The other participant said she had done a previous diploma with Westover $\mathrm{C}$ and therefore felt a much stronger allegiance there.

Perceived power and control. Participants described day-to-day situations where they would encounter differences between institutions. When participants felt well informed about where to go for information or resources, they were more comfortable with their sense of belonging; when they experienced confusion, conflicting messages, or clear messages of exclusion, participants more closely identified with ambiguous belonging. For example, one participant described being given several different messages from front-line staff about how to obtain a parking pass because of his collaborative status, leading to frustration: "more of a disconnect on the student's end" (BTech participant). A common concern among East-Way BScN participants was being restricted from booking study rooms in the Wayland U Health Sciences library. While they acknowledged that there was an Eastman C Health Sciences library two buildings away, the Wayland U library is open for longer hours and has additional resources. Furthermore, students often work in mixed groups, with Wayland U and East-Way C students. Consistently having to ask the Wayland U student to book a room for the group reinforced a perception of being less.

Daily reminders. Participants discussed the impact of the frequency with which they were reminded of being a collaborative student. One participant's experience em- 
bodied the impact of a sudden reminder that she was different from other university students, when taking public transportation to a student-run event:

I felt embarrassed because it's total judgment. [To participate] we had to take a bus to a different site to do some kind of volunteer thing. And for the whole time waiting for the bus I was, like, "Shoot, my Eastman C card, they're going to see my Eastman C card.” Everyone’s like, "You got your student cards?” And they've all got their Wayland U cards. Meanwhile, I've got my Wayland U card for the gym, yes, but I've got my Eastman $\mathrm{C}$ card for the bus. So literally getting on the bus it was a sleeve, magic trick. It was like this, the most discrete flash of the card, because I didn't want somebody to be, like, "Is that an Eastman C card?" But if they were to see it, immediately there's the judgment: "You're an Eastman C student? Why are you at this function?" (East-Way BScN participant)

This participant did not disclose her status as a collaborative student for fear of being perceived as less.

The results of this study paint a picture of mixed student experiences. While all participants were positive about their academic programs, the experiences of being a collaborative student varied between highly positive and distressingly problematic.

\section{Discussion}

This study's findings suggest that the greater societal perceptions of differences between colleges and universities may be a contributing factor to the experiences of Wayland U, Eastman C, and Westover C students being treated differently by peers, faculty, and staff at all three institutions. Traditionally, universities have been seen as elite enclaves for predominantly white, middle-class men (Kezar, 1999). While this image is changing with a more diverse student body and greater access through different educational pathways (Paulson, 2014; Ulhøi, 2005), charges of elitism remain. One of the challenges is that elitism should not be confused with quality (Gordon, 2010), a characteristic that is deemed highly desirable in most institutions. As described by Weerts, Freed, and Morphew (2014), historically, societal views of higher education have largely been influenced by portrayals in the public media. More recently, with larger numbers of people attending higher education, colleges and universities have paid greater attention to influencing public perceptions through branding and focusing on their image and reputation, particularly as the media images associated with university life have changed. One study found that the reputation of the institution had a greater impact on graduate hiring decisions than the posted qualifications and skills for the positions (Morley \& Aynsley, 2007). Thus, promoting and maintaining a positive, publicly held image is important while at the same time focusing on quality rather than elitism. While the above analyses are based primarily on US and European experiences, there are parallels that can be drawn with the Ontario experience. This is particularly true given the differences in status that are perceived between colleges and universities (Paulson, 2014). Many participants in this study described experiences of being caught in these differing perceptions.

Several Ontario-based reports have discussed the structure, institutional incentives, student characteristics, and academic success of college/university collaborations (Boggs \& Trick 2009; Kerr et al., 2010; Trick, 2013). Decock, McCloy, Liu, and Hu (2011) analyzed 
student satisfaction surveys to uncover student expectations and successes with collaborative programs, and Cameron (2005) reported on student experiences in two-plus-two collaborative programs. However, none of these reports focused on the lived experiences of students engaged in integrated collaborative programs, where students engage with two institutions simultaneously.

Student experience is closely related to student engagement in learning (Wolf-Wendel, Ward, \& Kenzie, 2009) and achievement (Kahu, 2013), which have been shown to have a significant predictive effect. Student engagement-an interaction of broader socio-political context and individual elements-can be derailed in higher education by contextual influences such as academic culture and disciplinary power, resulting in student disconnection (Mann, 2001). An intrinsic bias aligned with dominant groups exists in academic institutions and impacts the retention of non-conventional students (Lawrence, 2005; Thomas, 2002). Holistic approaches to engage the student as a whole person, complete with their unique story, knowledge, and experiences, are encouraged to reduce this inadvertent alienation (Dall'Alba \& Barnacle, 2007; Lawrence, 2005). Thus, it is imperative to focus on engaging, not alienating, these students from the onset of their studies and to intentionally improve their day-to-day experiences.

As a relatively small subset of academic institutions, collaborative programs are, understandably, governed by memorandums of understanding (MOUs) that outline rules and restrictions on everything from reputation and branding to cost-sharing and administration. The findings of this study suggest that these MOUs should be re-examined in light of their impact on the student experience. Do the admissions policies impact students' access to on-campus housing or bursaries? Are there impediments to students having ID cards for access to public transportation? Are collaborative-program students permitted to take courses (elective or required) alongside university-only students? Are students expected to monitor multiple email accounts? Having student representatives on steering committees for collaborative programs could raise awareness of how decisions made at the executive level can impact the lives of students.

Some participants described experiences of being stigmatized because of their collaborative status. While arguably collaborative students do not face the same degree of stigma as other marginalized groups, stigma has been shown to be particularly resistant to amelioration (Goffman, 1963; Link \& Phelan, 2001). Research has consistently demonstrated that education alone does not reduce stigma. However, intermingling groups working for a common purpose has been shown to be effective (Corrigan, 2005). Promoting opportunities for collaborative students to learn and socialize together with other university students from early in their programs may be of benefit. Similarly, college and university policies and procedures should be examined in relation to any unintended stigmatizing effect on collaborative students. For example, are there barriers to collaborative students playing in varsity sports at either institution? Are collaborative students excluded from booking study rooms in libraries? Faculty may also inadvertently or consciously contribute to stigmatizing experiences through in-class comments.

\section{Study Strengths and Limitations}

This research study uncovered a different perspective on the student experience than is typically captured by program-specific evaluations or surveys. Each program is struc- 
tured in a slightly different way, varying in administrative policies, the manner in which students interact with peers, the geographical distance between institutions, and whether there are similar cohorts of university-only students. All team members participated in all phases of the project, leading to rich discussions and insights that would not have been possible without these interdisciplinary and interinstitutional collaborations. Faculty researchers were all embedded within their respective programs and had detailed knowledge of institutional policies. The inclusion of student researchers as facilitators in the focus groups enabled participants to freely express their perceptions and experiences without the presence of faculty authority figures. Rich discussions within focus groups and within researcher team meetings occurred because of the cross-pollination of experiences. However, only a small fraction of the total student population participated in this qualitative study to offer their insights. While this allowed for rich descriptions of their experience, it may be that only students who had a strong message to convey participated. Also, using focus groups as the only source of data collection may have resulted in the group concentrating on and reinforcing the experiences of the most vocal students. Furthermore, only collaborative programs associated with one university were included in the study. Other partnerships may have different characteristics and outcomes.

\section{Conclusions}

Joint college/university programs are becoming increasingly common as governments attempt to address imbalances in student access to education as well as societyand industry-driven human resource requirements. While previous research and analyses have focused on factors leading to the success of these partnerships, this study provides a glimpse into the day-to-day lives and experiences of students enrolled in these programs. Although all participants reported positive perceptions of their academic programs, the experience of having a "dual identity" was positive for some and problematic for others. The experiences of inadequate communication and stigma or discrimination were common across programs, underscoring the urgency of addressing these issues that impact the student experience. By engaging a research team and participants from across programs and faculties, greater understanding of some of the influences on the differing perceptions was possible. Also, there is great value in fully embracing the student voice on issues of importance to students by engaging them as research partners through every phase of the research process.

This study leads to additional research questions and suggestions for further research. A multi-site study exploring the experiences of students at different institutions, with a mix of different program structures, would begin to unravel what is unique to a given context and what issues reflect larger societal values. It is important to understand faculty and staff perceptions of collaborative programs and the students who are enrolled in those programs. A larger quantitative study based on the results of this study could confirm the extent to which these experiences are shared by students within collaborative programs and within university or college stand-alone programs. This study could also explore whether students with different demographic characteristics have differing experiences, and, if so, to what degree.

The findings of this study are currently being used to facilitate a collaborative student advocacy group. This group, in partnership with faculty and administrators, will 
design, implement, and evaluate various strategies within the institutions to address the collaborative student experience. Student experience and student engagement are critical to student success, which is one of the goals of every educational institution. Thus, it is imperative to address the student experience of living the "dual life" of being engaged in collaborative college/university studies.

\section{Acknowledgements}

This research was supported by a grant from the President's Forward with Integrity Fund and the Dean of Engineering, McMaster University. We wish to thank Rosemary Martin and Helene St-Pierre for their assistance in translating the abstract into French.

\section{References}

Armstrong, P. (2008). Report of the College-University Consortium Council 20072008. Retrieved from http://oncat.ca/files_docs/content/pdf/en/oncat_research_ reports/oncat_research_reports_26.pdf

Audas, R., \& Willms, J. D. (2001). Engagement and dropping out of school: A lifecourse perspective. Hull, QC: Human Resources Development Canada Publications Centre. Retrieved from http://sbisrvntweb.uqac.ca/archivage/15292281.pdf

Boggs, A., \& Trick, D. (2009). Making college-university collaboration work: Ontario in a national and international context. Toronto, ON: Higher Education Quality Council of Ontario.

Cameron, C. (2005). Experiences of transfer students in a collaborative baccalaureate nursing program. Community College Review, 33(2), 22-44. doi: 10.1177/009155210503300202

Corrigan, P. W. (Ed.) (2005). On the stigma of mental illness: Practical strategies for research and social change. Washington, DC: American Psychological Association. doi:10.1037/10887-000

Dall'Alba, G., \& Barnacle, R. (2007). An ontological turn for higher education. Studies in Higher Education, 32, 679-691. doi:10.1080/03075070701685130

Decock, H., McCloy, U., Liu, S., \& Hu, B. (2011). The transfer experience of Ontario colleges who further their education - An analysis of Ontario's college graduate satisfaction survey. Toronto, ON: Higher Education Quality Council of Ontario. Retrieved from http://www.heqco.ca/SiteCollectionDocuments/ TransferExperienceofOntarioCollegeGraduates.pdf

Denzin, N. K., \& Lincoln, Y. S. (2011). The Sage handbook of qualitative research (4th ed.). Thousand Oaks, CA: Sage.

Duggleby, W. (2005). What about focus group interaction data? Qualitative Health Research, 15(6), 832-840. doi:10.1177/1049732304273916

Elffers, L., Oort, F. J., Karsten, S. (2012). Making the connection: The role of social and academic school experiences in students' emotional engagement with school in postsecondary vocational education. Learning and Individual Differences, 22(2), 242-250. doi:10.1016/j.lindif.2011.08.005 
Finn, J. D. (1989). Withdrawing from school. Review of Educational Research, 59(2), 117-142.

Finn, J. D. (1993). School engagement and students at risk. Washington, DC: National Center for Educational Statistics. Retrieved from http://files.eric.ed.gov/fulltext/ ED362322.pdf

Fredricks, J. A., Blumenfeld, P. C., \& Paris, A. H. (2004). School engagement: Potential of the concept, state of the evidence. Review of Educational Research, 74(1), 59-109.

Freeman, T. (2006). 'Best practice' in focus group research: Making sense of different views. Journal of Advanced Nursing, 56(5), 491-497. doi:10.1111/j.13652648.2006.04043.x

Garcia Bedolla, L. (2010). Good ideas are not enough: Considering the politics underlying students' postsecondary transitions. Journal of Education for Students Placed at Risk, 15(1), 18. doi:10.1080/10824661003634914

Goffman, E. (1963). Stigma: Notes on the management of spoiled identity. Englewood Cliffs, NJ: Prentice-Hall.

Gordon, J. A. (2010). Beyond anti-elitism: Black studies and the pedagogical imperative. Review of Education, Pedagogy \& Cultural Studies, 32(2), 129-144. doi:10.1080/10714411003799033

Hausmann, L. R. M., Schofield, J. W., \& Woods, R. L. (2007). Sense of belonging as a predictor of intentions to persist among African American and white first-year college students. Research in Higher Education, 48(7), 803-839.

Hollander, J. (2004). The social contexts of focus groups. Journal of Contemporary Ethnography, 33, 602-636. doi:10.1177/0891241604266988

Hunt, M. R. (2009). Strengths and challenges in the use of interpretive description: Reflections arising from a study of the moral experience of health professionals in humanitarian work. Qualitative Health Research, 19(9), 1284-1292.

Kahu, E. R. (2013). Framing student engagement in higher education. Studies in Higher Education, 38(5), 758-773. doi:10.1080/03075079.2011.598505

Kerr, A., McCloy, U., \& Liu, S. (2010). Forging pathways: Students who transfer between Ontario colleges and universities. Toronto, ON: Higher Education Quality Council of Ontario. Retrieved from http://www.heqco.ca/SiteCollectionDocuments/ ForgingPathwaysENG.pdf

Kevern, J., \& Webb, C. (2001). Focus groups as a tool for critical social research in nurse education. Nurse Education Today, 21, 323-333. doi:10.1054/nedt.2001.0563

Kezar, A. J. (1999). The diverse campus: Broadening our ideal to incorporate all voices. New Directions for Higher Education, 1999(105), 25-34. doi:10.1002/he.10502

Kirby, D. (2007). Change and challenge: Ontario's collaborative baccalaureate nursing programs. Canadian Journal of Higher Education, 37(2), 29-46.

Kirby, D. (2008). Advancing articulation: Models of college-university collaboration in Canadian higher education. College Quarterly, 11(4), 1-7. 
Lawrence, J. (2005). Addressing diversity in higher education: Two models for facilitating student engagement and mastery. In Higher education in a changing world: Research and development in higher education. Proceedings of the $28^{\text {th }}$ HERDSA Annual Conference, 3-6 July 2005, Sydney, Australia (pp. 243-252). Milperra, Australia: Higher Education Research and Development Society of Australasia.

Link, B. G., \& Phelan, J. C. (2001). Conceptualizing stigma. Annual Review of Sociology, 27, 363-385. doi:10.1146/annurev.soc.27.1.363

Mann, S. J. (2001). Alternative perspectives on the student experience: Alienation and engagement.Studiesin Higher Education,26(1),7-19.doi:10.1080/03075070020030689

Morley, L., \& Aynsley, S. (2007). Employers, quality and standards in higher education: Shared values and vocabularies or elitism and inequalities? Higher Education Quarterly, 61(3), 229-249. doi:10.1111/j.1468-2273.2007.00353.x

Morse, J. M., \& Field, P. (1995). Qualitative methods for health professionals (2nd ed.). Thousand Oaks, CA: Sage.

Ontario Universities Application Centre. (2014). Collaborative university college programs. Retrieved from http://www.ouac.on.ca/docs/101/collab_b.pdf

Paulsen, M. B. (Ed.).(2014). Higher education: Handbook of theory and research (Vol. 29). Dordrecht, The Netherlands: Springer Science + Business Media. doi:10.1007/97894-017-8005-6_6

Pringle, D., Green, L., \& Johnson, S. (2004). Nursing education in Canada: Historical review and current capacity. Ottawa, ON: The Nursing Sector Study Corporation. Retrieved from https://www.nurseone.ca/ /media/nurseone/page-content/pdf-en/ nursing_education_canada_e.pdf

Smith, W. L., \& Zhang, P. (2009). Students' perceptions and experiences with key factors during the transition from high school to college. College Student Journal, 43(2), $643-657$.

Thomas, L. (2002). Student retention in higher education: The role of institutional habitus. Journal of Education Policy, 17, 423-442. doi:10.1080/02680930210140257

Thorne, S. (2008). Interpretive description. Walnut Creek, CA: Left Coast Press.

Trick, D. (2013). College-to-University Transfer Arrangements and Undergraduate Education: Ontario in a National and International Context. Toronto, ON: Higher Education Quality Council of Ontario. Retrieved from http://www.heqco.ca/ SiteCollectionDocuments/Transfer\%20Arrangements\%20Trick\%20ENG.pdf

Ulhøi, J.P. (2005). Postgraduate education in Europe: An intersection of conflicting paradigms and goals. The International Journal of Educational Management, 19(4), 347-358. doi:10.1108/09513540510599662

Warr, D. (2005). "It was fun...but we don't usually talk about these things": Analyzing sociable interaction in focus groups. Qualitative Inquiry, 11(2), 200-225. doi:10.1177/1077800404273412 
Weerts, D. J., Freed, G. H., \& Morphew, C. C. (2014). Organizational identity in higher education: Conceptual and empirical perspectives. In M. B. Paulsen (Ed.), Higher education: Handbook of theory and research (Vol. 29; pp. 229-278). Dordrecht, The Netherlands: Springer Science + Business Media. doi:10.1007/978-94-017-8005-6_6

Wilkinson, S. (1998). Focus groups in feminist research: Power, interaction, and the co-construction of meaning. Women's Studies International Forum, 21(1), 111-125. doi:10.1016/So277-5395(97)00080-0

Wilkinson, C., Rees, C., \& Knight, L. (2007). "From the heart of my bottom": Negotiating humor in focus group discussions. Qualitative Health Research, 17(3), 411422. doi:10.1177/1049732306298375

Wolf-Wendel, L., Ward, K., \& Kinzie, J. (2009). A tangled web of terms: The overlap and unique contribution of involvement, engagement, and integration to understanding college student success. Journal of College Student Development, 5O(4), 407-428. doi:10.1353/csd.0.0077

Zawaduk C., Duncan S., Mahara M., Tate B., Callaghan D., McCullough D., . . . Van Neste-Kenny J. (2014). Mission possible: Twenty-five years of university and college collaboration in baccalaureate nursing education. Journal of Nursing Education, 53(10), 580-588. doi:10.3928/01484834-20140922-04

Zorzi, R., Engman, A., Barry, J., Lauzon, C., Coy, D., \& Yen, W. (2007). Implementation evaluation of Ontario's collaborative nursing programs. Final Report for CUCC (The College-University Consortium Council). Retrieved from http://oncat.ca/files_docs/ content/pdf/en/oncat_research_reports/oncat_research_reports_3.pdf

\section{Contact Information}

Janet Landeen

School of Nursing

McMaster University

landeen@mcmaster.ca

Janet Landeen completed a BScN from the University of Connecticut, an MEd from the University of Victoria, and a PhD from the University of Toronto. Following a 20-year career in hospital and community-based psychiatric mental health nursing, she joined McMaster University in 1987, where she is an associate professor. She was Assistant Dean of the BScN Program from 2004 to 2012 and was immersed in issues related to the collaborations with Mohawk and Conestoga Colleges. She has a long research career in issues related to teaching and learning, in addition to her clinical research on hope and chronic illness.

Nancy Matthew-Maich completed a BScN, MSc(T), and PhD from McMaster University. She has been on faculty as a professor in the School of Nursing at Mohawk College since 1987 and with the collaborative McMaster University-Mohawk College BScN program since 2000. She is currently involved in teaching and research as a Professor of Research and Innovation, engaging and mentoring faculty and students in research innovations. 
She is active in a number of health education, healthcare improvement, and health technology research initiatives.

Leslie Marshall, BSc, MSc, is the Learning and Development Consultant at the Centre for Teaching and Learning, Mohawk College. He taught in the Mohawk-McMaster collaborative Medical Radiation Sciences program for 12 years. He has worked in curriculum development, faculty development, curriculum quality, and learning outcomes assessment both inside Mohawk and with other institutions. His research interests include investigations into the working identities of both college educators and students. He is a co-author of the HECQO publication Learning Outcomes Assessment: A Practitioner's Handbook.

Lisa-Anne Hagerman completed a Diploma in Nursing from Fleming College, a BScN from Queen's University, an MBA from Argosy University, an $\mathrm{MScN}$ from York University, a Doctor of Education with specialization in higher education from Argosy University, and a Post-Graduate Certificate in Technology-Based Teaching and Learning from Athabasca University. She has been on faculty in the School of Health and Life Sciences at Conestoga College since 2006, where she is a professor of nursing in the BScN program. She works with students in the clinical and theoretical setting and engages in activities related to enhancing student learning within a technological learning environment.

Lindsay Bolan completed a BA in Media, Information, and Technoculture and MA in Media Studies from the University of Western Ontario. She has worked in the education marketing sector for 10 years as a recruiter, admission officer, marketing strategist, and communications instructor. She has been involved in academic and administrative research projects related to student success, college to university pathways, and the postsecondary advertising landscape. Lindsay is currently the Manager, Strategic Recruitment and Enrolment for the Faculty of Engineering at McMaster University.

Maurine Parzen, RN, BScN, MScT, PhD, has been a Professor for 17 years in the nursing program at Mohawk College. Throughout the years she has taught in the Collaborative McMaster, Mohawk, Conestoga BScN program as well as coordinated the RPN to BScN program at the Mohawk site for 7 years. She also has teaching experience in the Mohawk College Practical Nursing, and International Educated Bridging programs.

Maria Pavkovic completed her BScN from McMaster University (Mohawk College) in 2014. She completed her RPN diploma- specialization with Aboriginal communities from Mohawk College in 2010. Her passion is working with Aboriginal communities; previously employed with Health Canada in its First Nations and Health Inuit Branch as a public health nurse in Saddle Lake Cree Nation, Alberta. She is currently working for the Government of Nunavut as the Regional Tuberculosis Case Manager while pursuing a master's of public health at the University of Alberta.

Christine Riehl completed her BScN from McMaster University (Conestoga College) in 2014. She is currently employed at Huron Perth Healthcare Alliance in the Stratford General Hospital Emergency Unit, Stratford, Ontario. 
Joshua Carvalho completed his BScN from McMaster University (Mohawk College) in 2015, where he also served as President of the Nursing Student Society during that year. Currently, he is employed at St. Joseph's Healthcare Hamilton, in the Chest, Head \& Neck and Surgical Stepdown unit, Hamilton, Ontario.

Natasha Bilau completed her BScN from McMaster University (Mohawk College) in 2014. She is currently working at St. Joseph's Healthcare Hamilton (Ontario) on an acute mental health unit.

Zetian Zhang completed her BMRSc from McMaster University and received an Advanced Diploma from Mohawk College in 2014. She then completed her advanced diploma for Magnetic Resonance Imaging in 2016 at Fanshawe College. She is currently employed in diagnostic imaging at Hamilton Health Sciences, McMaster University Medical Center Site and at Niagara Health, St. Catharines and Greater Niagara General Site.

Sheri Oliver is a nurse with many years of experience in the clinical setting as well in varied administrative roles. She has held dual registration as a Registered Practical Nurse (RPN) and a Registered Nurse (RN) and completed her BScN from McMaster University (Conestoga College) in 2014. She is the recipient of an academic and leadership recognition award and has participated in research activities with the Registered Practical Nurses Association of Ontario (RNAO) and the Registered Nurses' Association of Ontario (RNAO). Sheri is currently employed as an RN at St. Mary's General Hospital in Kitchener, Ontario.

Jacob Cottreau completed his BMRSc from McMaster University and received an Advanced Diploma from Mohawk College in 2015. He has recently moved to Winterthur, Switzerland, where he is employed as a radiation technologist at the Kantonsspital Winterthur.

Bhavin Shukla completed his BTech from McMaster University and an Advanced Diploma and a Business Certificate from Mohawk College in 2013. He completed his MEng from McMaster University in 2015. He is currently employed as an Electrical Engineering Officer - Automation and Controls at Canada Post, Mississauga, Ontario. 